\title{
ANALISIS FAKTOR-FAKTOR YANG MEMPENGARUHI HARGA CABAI MERAH DI KOTA BANDA ACEH
}

\author{
(Analysis Of The Factors That Affect The Price Of Red Peppers In The City Banda Aceh)
}

\author{
Rahmatul Fajri ${ }^{1}$, T. Fauzi ${ }^{1}$, Indra $^{1 *}$ \\ ${ }^{1}$ Program Studi Agribisnis, Fakultas Pertanian, Universitas Syiah Kuala
}

\begin{abstract}
Abstrak. Cabai merah merupakan komoditas holtikultura yang sangat digemari oleh masyarakat indonesia. Ciri dan sayuran ini rasanya pedas dan aromanya khas, sehingga bagi orang-orang tertentu dapat membangkitkan selera makan. Permintaan terhadap cabai merah untuk kebutuhan sehari-hari dapat berfluktuasi yang disebabkan karena naik turunnya harga cabai merah yang terjadi di pasar eceran. Penelitian ini bertujuan untuk mengetahui faktor-faktor apa saja yang mempengaruhi naik-turunnya harga cabai merah di Kota Banda Aceh. Lokasi penelitian dilakukan di Kota Banda Aceh dengan objek penelitian adalah Pedagang cabai merah di Kota Banda Aceh. Data yang digunakan adalah primer dan data sekunder. Metode analisis yang digunakan adalah Uji Asumsi Klasik dan Regresi Linear Berganda. Hasil penelitian menunjukkan bahwa secara serempak variabel produksi, curah hujan, jumlah penduduk, dan jumlah rumah makan berpengaruh positif atau signifikan terhadap harga cabai merah di Kota Banda Aceh. Secara parsial variabel curah hujan, jumlah penduduk, dan jumlah rumah berpengaruh positif atau signifikan terhadap harga cabai merah, sedangkan variabel produksi tidak berpengaruh positif terhadap harga cabai merah di Kota Banda Aceh.
\end{abstract}

Kata Kunci : Produksi, Curah Hujan, Jumlah Penduduk, Jumlah Rumah Makan, Harga Cabai Merah

Abstract. Red pepper is a horticultural commodity that is loved by the people of indonesia. these characteristics and vegetables taste spicy and distintive aroma, so for people can arouse appetite. The demand for red peppers for daily needs may fluctuate due to the ups and downs of the price of red peppers occuring in the retail market. This research aimed to analyze the factors affecting chili prices in the Kota Banda Aceh city. The location of this research is done in Banda Aceh city, the object of research is red pepper traders in Banda Aceh city. The data used is primary and secondary data. The analytical methods used are classical assumptionbtest and multiple linear regression. The results showed that simultaneously variable production, rainfall, population, and number of restaurants have a positive or significant impact on the price of red peppers in the city Banda Aceh. Partially variable of rainfall, population, and number of restaurants have a positive or significant impact on the price of red peppers while the production variable does not positively affect the price of red peppers in the city Banda Aceh.

Keywords : Production, Rainfall, Total Population, Total of Restaurant, chili prices,

\section{PENDAHULUAN}

Sektor pertanian merupakan salah satu basis yang sangat diharapkan dalam menunjang pertumbuhan ekonomi baik pada saat ini maupun dimasa yang akan datang. Untuk itu pembangunan di sektor pertanian perlu mendapat perhatian yang serius dari berbagai pihak, mengingat bahwa hampir sebagian besar masyarakat indonesia hidup dan bermata pencaharian sebagai petani.

Cabai merah merupakan komoditas hortikultura yang sangat digemari oleh masyarakat indonesia dan mempunyai nilai ekonomi tinggi. Ciri dan jenis sayuran ini rasanya pedas dan aromanya khas, sehingga bagi orang-orang tertentu dapat membangkitkan selera makan. Meskipun cabai merah bukan bahan pangan utama bagi masyarakat, namun komoditi ini tidak dapat ditinggalkan, harus tersedia setiap hari dan harus dalam bentuk segar. Ketersediaannya secara teratur setiap hari bagi ibu rumah tangga menjadi suatu keharusan. 
Cabai merah tersebar di Indonesia. Provinsi Aceh merupakan salah satu provinsi yang memiliki daerah sentra produksi tanaman cabai merah. Adapun produksi cabai merah di Provinsi Aceh pada tahun 2009-2014.

Tabel 1. Produksi Cabai Merah di Aceh Tahun 2009-2014

\begin{tabular}{|c|c|c|c|}
\hline No & Tahun & Produksi (Ton) & Produktivitas (Ton) \\
\hline 1 & 2010 & 182,60 & 56,05 \\
\hline 2 & 2011 & 203,79 & 61,85 \\
\hline 3 & 2012 & 227,64 & 54,83 \\
\hline 4 & 2013 & 89,86 & 81,61 \\
\hline 5 & 2014 & 100,13 & 83,47 \\
\hline
\end{tabular}

Sumber : BPS Aceh

Dari tabel di atas dapat kita lihat bahwa produksi cabai merah di aceh terus meningkat setiap tahunnya akan tetapi pada tahun 2013-2014 mengalami penurunan yang bervariasi. Produksi cabai merah yang paling tinggi di provinsi aceh pada tahun 2012.

Kota Banda Aceh juga merupakan salah salah satu penghasil cabai merah. Adapun luas tanam, luas panen dan produksi dapat dilihat pada tabel 2 di bawah ini :

Tabel 2. Produksi Cabai Merah di Kota Banda Aceh Tahun 2011-2015

\begin{tabular}{|c|c|c|c|c|}
\hline No & Tahun & Luas Tanam (Ha) & Luas panen (Ha) & Produksi (Ton) \\
\hline 1 & 2011 & 2 & 2 & 0,3 \\
\hline 2 & 2012 & 3 & 3 & 0,7 \\
\hline 3 & 2013 & 2 & 2 & 2 \\
\hline 4 & 2014 & 4 & 4 & 0,32 \\
\hline 5 & 2015 & 2 & 2 & 0,4 \\
\hline
\end{tabular}

Sumber : Dinas Pertanian Kota Banda Aceh (diolah)

Harga suatu komoditas dan jumlah yang diperjualbelikan ditentukan oleh permintaan dan penawaran dari komoditas tersebut. Menurut sukirno (2005) dalam hukum permintaan dijelaskan sifat hubungan antara permintaan suatu barang dengan tingkat harganya.

Tabel 3. Harga Cabai Merah di Tingkat Produsen dan Konsumen (Pasar Induk Lambaro) Kecamatan Ingin Jaya Tahun 2016

\begin{tabular}{|c|c|c|c|c|c|c|c|c|}
\hline \multirow[t]{2}{*}{ Bulan } & \multicolumn{2}{|c|}{ Minggu ke- 1} & \multicolumn{2}{|c|}{ Minggu ke- 2} & \multicolumn{2}{|c|}{ Minggu ke- 3} & \multicolumn{2}{|c|}{ Minggu ke- 4} \\
\hline & Prod & Kons & Prod & Kons & Prod & Kons & Prod & Kons \\
\hline Jan & 25.000 & 27.000 & 25.000 & 27.000 & 25.000 & 27.000 & 25.000 & 27.000 \\
\hline Feb & 29.000 & 35.000 & 29.000 & 35.000 & 25.000 & 37.000 & 25.000 & 37.000 \\
\hline Mar & 25.000 & 37.000 & 25.000 & 37.000 & 25.000 & 37.000 & 22.500 & 35.000 \\
\hline Apr & 19.500 & 25.000 & 25.000 & 27.000 & 25.000 & 27.000 & 16.000 & 20.000 \\
\hline Mei & 24.000 & 28.000 & 35.000 & 40.000 & 35.000 & 40.000 & 35.000 & 40.000 \\
\hline Jun & 23.000 & 28.000 & 23.000 & 28.000 & 20.000 & 25.000 & 23.000 & 28.000 \\
\hline Juli & 35.000 & 40.000 & 35.000 & 40.000 & 35.000 & 40.000 & 35.000 & 40.000 \\
\hline Aug & 40.000 & 42.000 & 35.000 & 38.000 & 35.000 & 38.000 & 40.000 & 42.000 \\
\hline Sep & 42.000 & 45.000 & 42.000 & 45.000 & 42.000 & 45.000 & 45.000 & 47.000 \\
\hline Okt & 68.000 & 70.000 & 68.000 & 70.000 & 68.000 & 70.000 & 75.000 & 80.000 \\
\hline Nov & 85.000 & 90.000 & 85.000 & 90.000 & 85.000 & 90.000 & 90.000 & 95.000 \\
\hline Des & 35.000 & 40.000 & 35.000 & 40.000 & 35.000 & 40.000 & 35.000 & 40.000 \\
\hline
\end{tabular}

Sumber : Dinas Pertanian dan Tanaman Pangan Kabupaten Aceh Besar (diolah) 
Kenaikan harga cabai sangat tergantung pada musim panen dan musim tanam serta pengaruh iklim. Disamping itu kenaikan harga juga berkaitan dengan kegiatan pemasaran. Bila dibandingkan dengan harga didaerah konsumen harga cabai didaerah produsen lebih rendah. Beberapa faktor yang mempengaruhi diantaranya faktor angkutan, rendahnya daya tahan cabai, dan daya beli masyarakat yang rendah (Santika, 1999).

Walaupun demikian pada saat tertentu harga cabai dapat melonjak naik, sehingga memberikan nilai tambah bagi petani. Lonjakan harga cabai ini antara lain disebabkan oleh gangguan musim dan hari raya tertentu. Kenaikan harga tersebut dapat berlipat ganda kalau gangguan musim terjadi bersamaan atau berdekatan dengan perayaan hari raya (Setiadi, 2004).

Oleh karena naik-turunnya harga cabai yang sangat ekstrim inilah maka peneliti merasa perlu untuk mengetahui bagaimana kecenderungan perubahan harga yang terjadi serta mengidentifikasi faktor-faktor yang mempengaruhi naik-turunnya harga cabai merah di Kota Banda Aceh.

Berdasarkan masalah diatas, maka tujuan dari penelitian ini adalah: Untuk mengetahui Faktor-faktor apa saja yang mempengaruhi naik-turunnya harga cabai merah di Kota Banda Aceh.

\section{METODE PENELITIAN}

Penelitian ini dilaksanakan di Kota Banda Aceh. Objek penelitian ini adalah Pedagang cabai merah di Kota Banda Aceh. Adapun Ruang lingkup penelitian ini terbatas pada variabel-variabel yang mempengaruhi harga cabai merah di Kota Banda Aceh. Adapun variabel-variabel yang menjadi fokus penelitian adalah harga, produksi, curah hujan, jumlah penduduk, dan jumlah rumah makan.

\section{Populasi, Metode dan Teknik Pengumpulan Data}

Populasi adalah sekelompok elemen lengkap yang biasanya berupa orang, transaksi atau kejadian yang menarik untuk dipelajari atau dijadikan sebagai objek penelitian. Populasi dalam penelitian ini adalah Pedagang cabai merah di Kota Banda Aceh. Pengambilan sampel untuk pedagang adalah menggunakan Multi Stage Sample yaitu sampel ditarik dari kelompok-kelompok populasi, tetapi tidak semua anggota kelompok populasi menjadi sampel (Nazir, 2005).

Pengumpulan data yang digunakan dalam penelitian ini terdiri dari :

a. Data primer yaitu data yang diperoleh dari pengamatan langsung di lapangan dan wawancara terhadap pedagang cabai merah.

b. Data sekunder yaitu data yang di peroleh dari perpustakaan, instansi terkait, browsing internet, atau literatur yang terkait dalam penelitian ini.

\section{Metode Analisis}

\section{Analisis Regresi Linear Berganda}

Analisis Faktor-Faktor Yang Mempengaruhi Harga Cabai Merah di Kota Banda Aceh 
Persamaan regresi linear berganda adalah suatu bentuk bentuk persamaan regresi linear antara beberapa variabel bebas dengan satu variabel (terikat). Regresi linear berganda berfungsi untuk mengetahui pengaruh atau hubungan variabel bebas dan variabel terikat. Regresi linear berganda adalah pengujian analisis statistik yang mempelajari pola hubungan antara dua atau lebh variabel yang di formulasikan secara matematis sebagai berikut :

$$
\mathrm{Y}=\mathrm{a}+\mathrm{b}_{1} \mathrm{X}_{1}+\mathrm{b}_{2} \mathrm{X}_{2}+\mathrm{b}_{3} \mathrm{X}_{3}+\mathrm{b}_{4} \mathrm{X}_{4}+\mathrm{e} \ldots . .(\mathrm{Nazir}, 2003)
$$

Dimana :

$$
\begin{array}{lll}
\mathrm{Y} & =\text { Harga cabai merah }(\mathrm{Rp} / \mathrm{Kg}) \\
\mathrm{a} & =\text { Konstanta } & \\
\mathrm{b} 1-\mathrm{b} 3 & =\text { Koefisien variabel } & \\
\mathrm{X} 1 & \text { = Produksi } & (\mathrm{Kg}) \\
\mathrm{X} 2 & \text { = Curah Hujan } & (\mathrm{mm}) \\
\mathrm{X} 3 & \text { = Jumlah Penduduk } & \text { (Jiwa) } \\
\mathrm{X} 4 & \text { = Jumlah Rumah makan } & \text { (Unit) } \\
\mathrm{e} & & =\text { faktor-faktor yang tidak terobservasi ( error) }
\end{array}
$$

Untuk mengetahui besarnya variabel bebas $(\mathrm{X})$ terhadap variabel terikat $(\mathrm{Y})$ secara serempak digunakan uji "F" yaitu :

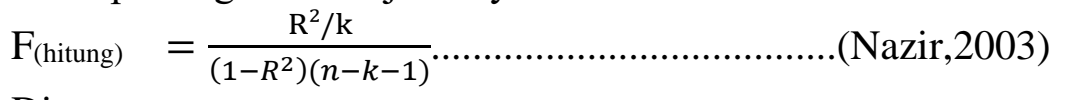

Dimana :

$\mathrm{R}^{2} \quad=$ Koefisien Determinasi

$\mathrm{k} \quad=$ jumlah variabel

$\mathrm{n} \quad$ = Banyaknya sampel

Sedangkan untuk mengetahui pengaruh masing-masing variabel bebas terhadap variabel terikat secara terpisah, maka digunakan uji t dengan rumus:

$$
\begin{aligned}
& \mathrm{t}_{\text {cari }}=\frac{\mathrm{ai}}{\mathrm{SE} a i} \text {........ } \\
& \text {..(Nazir, 2003) } \\
& \text { ai }=\text { koefisien regresi } \\
& \mathrm{SE}_{\mathrm{ai}}=\text { Standar eror }
\end{aligned}
$$

Dengan ketentuan :

$\mathrm{t}_{\text {(cari) }}>\mathrm{t}_{\text {(tabel) }}$, pada taraf nyata 0,05 maka terima Ha dan tolak $\mathrm{H}_{0}$ $\mathrm{t}_{\text {(cari) }}<\mathrm{t}_{\text {(tabel) }}$, pada taraf nyata 0,05 maka terima $\mathrm{H}_{0}$ dan tolak $\mathrm{Ha}$

\section{Uji Asumsi Klasik}

\section{a. Uji Asumsi Heteroskedastitas}

Uji heteroskedastitas digunakan untuk menguji apakah dalam sebuah model regresi terjadi ketidaksamaan varians dari residual suatu pengamatan ke pengamatan yang lain. Jika varian dari residual dari suatu pengamatan ke pengamatan yang lain tetap, maka disebut homoskedastitas. Dan jika varian berbeda disebut heteroskedastitas.

\section{b. Uji Multikolinearitas}


Menurut Imam Ghozali (2013: 91) Uji ini bertujuan untuk menguji apakah dalam model regresi ditemukan adanya korelasi antar variabel-variabel bebas. Untuk mengetahui ada tidaknya multikolinearitas antar variabel, dapat dilihat dari nilai Variance Inflation Factor (VIF) dari masing-masing variabel bebas terhadap variabel terikat. Jika nilai VIF lebih kecil dari 10 maka model tidak terdapat multikolinearitas, artinya tidak adanya hubungan antar variabel bebas.

\section{c. Uji Asumsi Normalitas}

Uji normalitas adalah untuk menguji apakah data penelitian berasal dari populasi yang sebarannya normal atau tidak. Uji ini perlu dilakukan karena perhitungan statistik parametrik memiliki asumsi normalitas sebaran.

\section{d. Uji Asumsi Autokorelasi}

Autokorelasi merupakan salah satu dari uji asumsi klasik yang digunakan untuk mengetahui apakah dala suatu model regresi linear terdapat korelasi antar kesalahan pengganggu dengan periode $t$ dengan kesalahan periode $t-1$ yang berarti kondisi saat ini dipengaruhi oleh kondisi sebelumnya dengan kata lain autokorelasi terjadi pada data time series.

\section{HASIL DAN PEMBAHASAN}

\section{Karakteristik Responden}

Dalam penelitian ini sampel yang diambil yaitu pedagang cabai merah yang ada di Kota Banda Aceh. Dari data yang diperoleh selama penelitian, responden yang menjadi sampel penelitian ditabulasikan dalam beberapa tabel untuk melihat karakteristik reponden yang terdiri dari jenis kelamin, usia, dan pendidikan.

\begin{tabular}{|c|c|c|c|}
\hline No. & Jenis Kelamin & Frekuensi (Jiwa) & Persentase (\%) \\
\hline 1. & Laki-laki & 22 & $81 \%$ \\
\hline 2. & Perempuan & 5 & $19 \%$ \\
\hline & Jumlah & $\mathbf{2 7}$ & $\mathbf{1 0 0} \%$ \\
\hline No. & Umur (Tahun) & Frekuensi (Jiwa) & Persentase (\%) \\
\hline 1. & $20-39$ & 13 & $48 \%$ \\
\hline 2. & $40-49$ & 10 & $37 \%$ \\
\hline 3. & $50-59$ & 4 & $15 \%$ \\
\hline & Jumlah & $\mathbf{2 7}$ & $\mathbf{1 0 0} \%$ \\
\hline No. & Tingkat & Frekuensi (Jiwa) & Persentase (\%) \\
\hline 1. & SD & 3 & $11 \%$ \\
\hline 2. & SMP & 10 & $37 \%$ \\
\hline 3. & SMA & 14 & $\mathbf{1 0 0} \%$ \\
\hline & Jumlah & $\mathbf{2 7}$ & \\
\hline
\end{tabular}

Analisis Faktor-Faktor Yang Mempengaruhi Harga Cabai Merah di Kota Banda Aceh 
Dari 4 tabel diketahui bahwa jenis kelamin responden pedagang cabai merah di Kota Banda Aceh lebih banyak laki-laki dibandingkan dengan perempuan. Dimana dapat dilihat dari tabel tersebut, frekuensi dari responden laki-laki yaitu 22 orang dengan persentase $81 \%$ sedangkan frekuensi dari responden perempuan yaitu 5 orang dengan persentase sebesar $19 \%$.

Dari tabel 5, dapat dilihat bahwa karakteristik responden pedagang cabai merah yang berdasarkan usia yang terbanyak adalah dengan rentang usia 20-39 tahun, yang berjumlah sebanyak 13 orang dengan persentase sebesar $48 \%$ kemudian diikuti oleh pedagang dengan rentang usia 40-49 yang berjumlah sebanyak 10 orang dengan persentase sebesar $37 \%$ dan pedagang dengan rentang usia 50-59 hanya berjumlah 4 orang dengan persentase $15 \%$.

Berdasarkan tingkat pendidikan terakhir, frekuensi terbanyak adalah responden dengan tingkat pendidikan terakhirnya yaitu SMA yang berjumlah 14 jiwa atau sebesar 52\% dari keseluruhan responden. Reponden yang memiliki tingkat pendidikan terakhir Sekolah Menengah Pertama (SMP) yaitu sebanyak 10 jiwa atau sebesar $37 \%$ dan reponden yang memiliki pendidikan terakhir Sekolah Dasar (SD) yaitu sebanyak 3 jiwa atau sebesar $11 \%$ dari keseluruhan responden.

\section{Uji Asumsi Klasik}

\section{a. Uji Multikolinearitas}

Coefficients $^{a}$

\begin{tabular}{|c|c|c|c|c|c|}
\hline \multirow{2}{*}{\multicolumn{2}{|c|}{ Model }} & \multirow[b]{2}{*}{$\mathrm{t}$} & \multirow[b]{2}{*}{ Sig. } & \multicolumn{2}{|c|}{ Collinearity Statistics } \\
\hline & & & & Tolerance & VIF \\
\hline \multirow[t]{5}{*}{1} & (Constant) & 2.373 & .039 & & \\
\hline & Produksi & -1.691 & .022 & .881 & 1.136 \\
\hline & Curah Hujan & 1.847 & .032 & .450 & 2.224 \\
\hline & Jumlah Penduduk & 3.712 & .004 & .899 & 1.112 \\
\hline & Jumlah RM & 2.716 & .022 & .468 & 2.137 \\
\hline
\end{tabular}

Dari tabel diatas diketahui bahwa masing-masing variabel bebas memiliki nilai toleransi $>0,10$ dan nilai $\mathrm{VIF}<10$, dimana produksi memiliki nilai toleransi $0,881>0,10$ dan nilai VIF $1,136<10$ sedangkan curah hujan memiliki nilai toleransi $0,450>0,10$ dan nilai VIF $2,224<10$, jumlah penduduk memiliki nilai toleransi $0,889>0,10$ dan nilai VIF $1,112<10$, dan jumlah rumah makan memiliki nilai toleransi $0,468>0,10$ dan nilai VIF 2,137< 10 sehingga dapat disimpulkan bahwa tidak terjadi multikolinearitas untuk setiap variabel bebas.

Analisis Faktor-Faktor Yang Mempengaruhi Harga Cabai Merah di Kota Banda Aceh 


\section{b. Uji Heteroskedastitas}

\begin{tabular}{|c|c|c|c|c|c|c|}
\hline \multicolumn{7}{|c|}{ Coefficients $^{\mathrm{a}}$} \\
\hline \multirow{2}{*}{\multicolumn{2}{|c|}{ Model }} & \multicolumn{2}{|c|}{ Unstandardized Coefficients } & \multirow{2}{*}{$\begin{array}{c}\begin{array}{c}\text { Standardized } \\
\text { Coefficients }\end{array} \\
\text { Beta }\end{array}$} & \multirow[b]{2}{*}{$\mathrm{t}$} & \multirow[b]{2}{*}{ Sig. } \\
\hline & & B & Std. Error & & & \\
\hline \multirow[t]{5}{*}{1} & (Constant) & 4.419 & 2.099 & & 2.106 & .061 \\
\hline & Produksi & -.020 & .031 & -.155 & -.664 & .52 \\
\hline & Curah Hujan & -.085 & .109 & -.257 & -.786 & .450 \\
\hline & Jumlah Penduduk & .440 & .175 & .581 & 2.514 & .071 \\
\hline & Jumlah RM & -.094 & .074 & -.407 & -1.269 & .233 \\
\hline
\end{tabular}

a. Dependent Variable: ABS_RES1

Dari tabel diatas dapat dilihat bahwa pada kolom Sig. Bahwa nilai signifikansi dari masing-masing variabel independent memiliki nilai yang lebih besar dari 0,05. Dimana dapat dilihat pada tabel tersebut nilai signifikansi variabel produksi sebesar 0,552 >0,05 kemudian nilai signifikansi variabel curah hujan sebesar $0,450>0,05$ nilai signifikansi variabel jumlah penduduk sebesar $0,071>0,05$ dan nilai signifikansi variabel jumlah rumah makan sebesar $0,099>0,05$.

\section{Uji Normalitas}

Tests of Normality

\begin{tabular}{|l|r|r|r|r|r|r|}
\hline & \multicolumn{4}{|c|}{ Kolmogorov-Smirnov } & \multicolumn{3}{|c|}{ Shapiro-Wilk } \\
\cline { 2 - 6 } & Statistic & df & \multicolumn{1}{c|}{ Sig. } & Statistic & df & Sig. \\
\hline Produksi & .202 & 15 & .102 & .929 & 15 & .261 \\
Curah Hujan & .131 & 15 & $.200^{*}$ & .941 & 15 & .399 \\
Jumlah Penduduk & .213 & 15 & .066 & .860 & 15 & .074 \\
Jumlah RM & .238 & 15 & .022 & .886 & 15 & .099 \\
Harga & .124 & 15 & $.200^{*}$ & .944 & 15 & .440 \\
\hline
\end{tabular}

a. Lilliefors Significance Correction

${ }^{*}$. This is a lower bound of the true significance.

Dari tabel diatas dapat dilihat pada kolom Sig. Bahwa nilai signifikansi untuk setiap variabel lebih besar dari 0,05. Dimana diketahui bahwa produksi memiliki nilai signifikansi sebesar 0,261 >0,05 kemudian nilai signifikansi variabel curah hujan sebesar 0,399>0,05 nilai signifikansi variabel jumlah penduduk sebesar $0,074>0,05$ dan nilai signifikansi variabel jumlah rumah makan sebesar 0,099 > 0,05.

Analisis Faktor-Faktor Yang Mempengaruhi Harga Cabai Merah di Kota Banda Aceh 


\section{Uji Autokorelasi}

\begin{tabular}{|l|r|r|r|r|r|}
\hline Model & \multicolumn{1}{|c|}{$\mathrm{R}$} & $\mathrm{R}$ Square & \multicolumn{1}{c|}{$\begin{array}{c}\text { Adjusted R } \\
\text { Square }\end{array}$} & \multicolumn{1}{c|}{ Std. Error of the Estimate } & \multicolumn{1}{c|}{ Durbin-Watson } \\
\hline 1 & $.911^{\mathrm{a}}$ & .830 & .762 & .16920 & .574 \\
\hline
\end{tabular}

a. Predictors: (Constant), X4, X1, X3, X2

b. Dependent Variable: $Y$

Dari tabel diatas dapat dilihat bahwa nilai Durbin-Watson sebesar 0,574 sedangkan nilai $\mathrm{dL}=0,69$ dan nilai $\mathrm{dU}=1,97$ artinya 0,574 yang berarti lebih kecil dari nilai batas bawah, dengan demikian dapat disimpulkan bahwa hasil regresi tersebut belum terbebas dari masalah autokorelasi positif.

\section{Regresi Linear Berganda}

Dari hasil perhitungan statistik dengan menggunakan program SPSS seperti yang terlihat pada tabel diatas, maka diperoleh persamaan regresi linear berganda sebagai berikut :

$Y=11,686-0,122 X 1+0,165 X 2+1,525 X 3+0,473 X 4$

Berdasarkan koefisien regresi dari masing-masing variabel bebas pada persamaan regresi diatas, maka dapat dijelaskan sebagai berikut :

a. Dalam penelitian ini diperoleh nilai konstanta sebesar 11,686. Artinya Jika nilai X1 $\mathrm{X} 2 \mathrm{X} 3$ dan X4 dianggap nol atau konstan, maka akan meningkatkan harga cabai merah di Kota Banda Aceh sebesar Rp11,686/Kg.

b. Koefisien regresi Produksi (X1) sebesar $-0,122$ artinya setiap peningkatan $1 \mathrm{Kg}$ produksi, maka akan menurunkan harga cabai merah sebesar Rp. 122 /Kg.

c. Koefisien regresi curah hujan (X2) sebesar 0,165 artinya setiap peningkatan $1 \mathrm{~mm}$ curah hujan, maka akan meningkatkan harga cabai merah sebesar Rp. 0,165/Kg.

d. Koefisien regresi Jumlah Penduduk (X3) sebesar 1,525 artinya setiap peningkatan 1 orang jumlah penduduk, maka akan meningkatkan harga cabai merah sebesar 1,525 $/ \mathrm{Kg}$.

e. Koefisien regresi Jumlah Rumah Makan (X4) sebesar 0,473 artinya setiap peningkatan 1 unit jumlah rumah makan, maka akan meningkatkan harga cabai merah sebesar $0,473 / \mathrm{Kg}$. 


\section{Uji Serempak ( Uji F)}

\begin{tabular}{|ll|r|r|r|c|c|}
\hline \multicolumn{1}{|c|}{ ANOVA } \\
\hline 1 & Sum of Squares & Df & Mean Square & F & Sig. \\
\hline & Regression & 1.400 & 4 & .350 & 12.224 & $.001^{\mathrm{a}}$ \\
& Residual & .286 & 10 & .029 & & \\
Total & 1.686 & 14 & & & \\
\hline
\end{tabular}

a. Predictors: (Constant), X4, X1, X3, X2

b. Dependent Variable: $Y$

Berdasarkan hasil Uji F ( secara simultan) diperoleh Fhitung sebesar 12,224 sedangkan Ftabel pada tingkat signifikansi $\alpha=5 \%$ adalah sebesar 2,59. Hal ini menunjukkan bahwa Fhitung>Ftabel $(12,224>2,59)$ dengan tingkat signifikansi 0,001. Dari hasil perhitungan ini dapat diabil suatu kesimpulan bahwa meneria Ha dan menolak Ho, artinya bahwa varibel produksi, curah hujan, jumlah penduduk, jumlah rumah makan secara bersamasama atau simultan berpengaruh secara signifikan terhadap harga cabai merah di Kota Banda Aceh.

\section{Uji Parsial (Uji t)}

\begin{tabular}{|c|c|c|c|c|c|c|}
\hline \multirow{2}{*}{\multicolumn{2}{|c|}{ Model }} & \multicolumn{2}{|c|}{ Unstandardized Coefficients } & \multirow{2}{*}{$\begin{array}{c}\begin{array}{c}\text { Standardized } \\
\text { Coefficients }\end{array} \\
\text { Beta }\end{array}$} & \multirow[b]{2}{*}{$\mathrm{t}$} & \multirow[b]{2}{*}{ Sig. } \\
\hline & & B & Std. Error & & & \\
\hline \multirow[t]{5}{*}{1} & (Constant) & 11.686 & 4.924 & & 2.373 & .039 \\
\hline & Produksi & -.122 & .072 & -.235 & -1.691 & .512 \\
\hline & Curah Hujan & .165 & .255 & .126 & 1.847 & .032 \\
\hline & Jumlah Penduduk & 1.525 & .411 & .510 & 3.712 & .004 \\
\hline & Jumlah RM & .473 & .174 & .517 & 2.716 & .022 \\
\hline
\end{tabular}

a. Dependent Variable: Harga

Secara parsial produksi berpengaruh positif terhadap harga cabai merah. Hal ini ditunjukkan oleh koefisien regresi untuk variabel produksi sebesar -0,122. Hasil pengujian statistik menunjukkan nilai t hitung untuk produksi sebesar -1,691 dengan nilai signifikansi sebesar 0,512. Sedangkan nilai t tabel sebesar 1,753. Karena nilai t hitung < t tabel $(1,691<1,753)$.

Secara parsial Curah Hujan berpengaruh positif terhadap harga cabai merah. Hal ini ditunjukkan oleh koefisien regresi untuk variabel Curah Hujan sebesar 0,165. Hasil pengujian statistik menunjukkan nilai $\mathrm{t}$ hitung untuk Curah Hujan sebesar 1,847 dengan nilai

Analisis Faktor-Faktor Yang Mempengaruhi Harga Cabai Merah di Kota Banda Aceh 
signifikansi sebesar 0,032 . Sedangkan nilai $\mathrm{t}$ tabel sebesar 1,753 . Karena nilai $\mathrm{t}$ hitung $>\mathrm{t}$ tabel $(1,847>1,753)$.

Secara parsial jumlah penduduk berpengaruh positif terhadap harga cabai merah. Hal ini ditunjukkan oleh koefisien regresi untuk variabel jumlah penduduk sebesar 1,525. Hasil pengujian statistik menunjukkan nilai t hitung untuk jumlah penduduk sebesar 3,712 dengan nilai signifikansi sebesar 0,004. Sedangkan nilai t tabel sebesar 1,753. Karena nilai thitung > $\mathrm{t}$ tabel $(3,712>1,753)$

Secara parsial jumlah rumah makan berpengaruh positif terhadap harga cabai merah. Hal ini ditunjukkan oleh koefisien regresi untuk variabel jumlah rumah makan sebesar 0,473. Hasil pengujian statistik menunjukkan nilai t hitung untuk jumlah rumah makan sebesar 2,716 dengan nilai signifikansi sebesar 0,02. Sedangkan nilai t tabel sebesar 1,753. Karena nilai t hitung $>$ t tabel $(2,716>1,753)$

\section{KESIMPULAN DAN SARAN}

\section{Kesimpulan}

Berdasarkan analisis data dan pembahasan yang telah dikemukakan pada bab sebelumnya, maka dapat ditarik beberapa kesimpulan penelitian sebagai berikut :

1. Secara serempak (simultan) variabel produksi, curah hujan, jumlah penduduk, dan jumlah rumah makan berpengaruh positif atau signifikan terhadap harga cabai merah di Kota Banda Aceh di mana Fhitung>Ftabel dengan tingkat signifikansi 0,001.

2. Secara parsial variabel curah hujan, jumlah penduduk, jumlah rumah makan berpengaruh positif atau signifikan terhadap harga cabai merah di Kota Banda Aceh. Sedangkan Produksi tidak berpengaruh positif atau tidak signifikan terhadap harga cabai merah di Kota Banda Aceh.

3. Variabel jumlah penduduk memiliki pengaruh lebih besar terhadap harga cabai merah dibandingkan dengan variabel Produksi, jumlah rumah makan, dan curah hujan.

\section{Saran}

Adapun saran yang dapat diberikan adalah sebagai berikut : Bagi penelitian selanjutnya hal yang dapat dijadikan sebagai pertimbangan yaitu dikarenakan prediksi dari 4 variabel independen terhadap harga cabai merah sebesar 83\% sedangkan sisanya 17\% dipengaruhi oleh faktor-faktor lain diluar model regresi. Maka bagi penelitian selanjutnya disarankan untuk menambah atau menggunakan variabel-variabel independen lainnya yang potensial.

Analisis Faktor-Faktor Yang Mempengaruhi Harga Cabai Merah di Kota Banda Aceh 


\section{DAFTAR PUSTAKA}

Agraini, Amalia. 2014. Analisis Pemasaran Cabai Merah Keriting di Desa Sidera Kecamatan Sigi Biromaru Kabupaten Sigi. Jurnal Fakultas Pertanian. Universitas Tadulako, Palu.

Azhari, A. 1992. Evaluasi Manajemen Produksi. BBFA. Yogyakarta.

BPS.2016. Banda Aceh Dalam Angka 2016. Badan Pusat Statistik. Banda Aceh.

Chairia. 2014. Analisis Permintaan dan Penawaran Cabai Merah di Provinsi Sumatera Utara. Jurnal Fakultas Pertanian. Universitas Sumatera Utara.

Ghozali, I. 2013 Aplikasi Analisis Multivariate dengan Program IBM SPSS 19. Edisi Kelima.

Universitas Dipenogoro. Semarang.

Nazir. 2003. Metode Analisis Kuantitatif Regresi Linear Berganda. Gramedia. Jakarta.

Nazir, M. 2005. Metode Penelitian. Ghalia Indonesia. Bogor.

Nofita, Indra. 2016. Analisis Keuntungan Usaha tani Cabai Merah Besar di Desa Andongsari Kecamatan Ambulu Kabupaten Jember. Jurnal Fakultas Pertanian. Universitas Muhammadiyah Jember.

Novitasari, Dewi. 2015. Analisis Penawaran Cabai Merah di Kabupaten Karanganyar. Jurnal Fakultas Pertanian. Universitas Sebelas Maret.

Palar, Nathania. 2016. Faktor-faktor yang Mempengaruhi Harga Cabai Rawit di Kota Manado. Jurnal Agri-Sosio Ekonomi. Manado.

Santika, Adhi. 1995. Agribisnis Cabe. Penerbit Penebar Swadaya. Jakarta.

Setiadi. 2004. Bertanam Cabai. Penebar Swadaya. Jakarta

Siahaan.S, Daniel. 2014. Efisiensi Penggunaan Faktor Produksi Usaha tani Cabai Merah. Jurnal Fakultas Pertanian. Universitas Sumatera Utara.

Soekartawi, 1993. Prinsip Dasar Pertanian. PT. Raja Grafindo Persada. Jakarta

Soekirno, 2003. Pengantar Teori Ekonomi Mikro. PT. Raja Grafindo Persada. Jakarta

Stanton, William J. 1993. Prinsip Pemasaran. Edisi ke 7. Alih Press. Jakarta

Sukirno, S. 2002 . Teori Ekonomi Mikro. Rajawali Press. Jakarta.

Sa'id, E.G dan Intan A.H. 2001. Manajemen Agribisnis. Ghalia Indonesia . Jakarta.

Tjiptono dan Fandy. 2004. Strategi Pemasaran. Andi, Yogyakarta.

Wahyudi. 2011. Panen Cabai Sepanjang Tahun. Agromedia Pustaka. Jakarta.

Warren J. Keegan. 2003. Manajemen Pemasaran Global. PT Indeks Gramedia. Jakarta.

Analisis Faktor-Faktor Yang Mempengaruhi Harga Cabai Merah di Kota Banda Aceh 